\title{
Do biological maturity and performance influence the training load of track and field athletes?
}

\section{A maturação sexual e o desempenho influenciam a carga de treinamento de atletas de atletismo?}

\author{
Ramon Cruz \\ (D) https://orcid.org/0000-0002-1308-5993 \\ Danilo L. Alves \\ (1) https://orcid. org/0000-0001-7583-0322 \\ Pablo R. Domingos ${ }^{1}$ \\ (D) httns://orcid org/0000-0003-3928-922X \\ Jefferson V. Freitas ${ }^{3}$ \\ (1) https://orcid. org/0000-0002-0582-7950 \\ Francisco Z. Werneck 4 \\ (1) https://orcid.org/0000-0003-1966-8820 \\ Romulo Bertuzzi \\ (1) https://orcid.org/0000-0002-0407-9620 \\ Fernando R. De-Oliveira ${ }^{5}$ \\ (D) https://orcid.ora/0000-0003-2811-8433 \\ Jorge R.P. Lima \\ (1) https://orcid.org/0000-0003-0073-8673
}

Abstract - It is necessary to clarify if BM and track and field performance can modulate the perception about RPE-session. The purpose of the present study was to verify if biological maturity and track and field-specific performance can be associated with training load (RPEsession method). Seventy-five young athletes (13-15 years old) of both genders participated in the present study. The experimental protocol lasted seven consecutive days. Performance tests (75-m running, long jump, 250-m running, shot put and 1000-m running) were made on the first day. After 48 hours, five days of track and field training it was prescribed, each day represents a training of each performance test. All training sessions had the same duration (120 min). The value of the training load was obtained multiplying the RPE value with training session duration (in minutes). For girls, the training load of $250-\mathrm{m}$ training was correlated with biological maturity $(r=-0.36, p=0.02, \mathrm{n}=37)$ and specific performance $(r=0.33, p=$ $0.04, n=37$ ). All other analyzes indicate that biological maturity and track and field-specific performance do not influence the training load based on RPE-session method. Training load based on RPE-session is not influenced by biological maturity and track and field-specific performance, therefore can be used to control the training load of young track and field athletes. To girls it is necessary a care to control the training sessions intensity of 250-m running.

Key words: Monitoring; Physical exertion; Training.

Resumo - É necessário esclarecer se a maturação biológica e o desempenho no atletismo podem modular a PSE da sessão. O objetivo do presente estudo foi verificar se a maturidade biológica e o desempenho específico no atletismo podem estar associados à carga de treinamento (método de PSE da sessão). Setenta e cinco jovens atletas (13-15 anos) de ambos os sexos participaram do presente estudo. O protocolo experimental durou sete dias consecutivos. Testes de desempenho (75 $\mathrm{m}$ de corrida, salto em distância, $250 \mathrm{~m}$ de corrida, arremesso de peso e $1000 \mathrm{~m}$ de corrida) foram feitos no primeiro dia. Após 48 horas, cinco dias de treinamento de atletismo foram prescritos, cada dia representa um treinamento de cada teste de desempenho. Todas as sessôes de treinamento tiveram a mesma duração $(120 \mathrm{~min})$. O valor da carga de treinamento foi obtido multiplicando o valor do PSE com a duracão da sessão de treinamento (em minutos). Para as meninas, a carga de treinamento de $250 \mathrm{~m}$ foi correlacionada com a maturidade biológica $(r=-0,36, p=0,02, n=37)$ e desempenho específico $(r=$ $0,33, p=0,04, n=37)$. Todas as outras análises indicam que a maturidade biológica e o desempenho específico no atletismo não influenciam a carga de treinamento com base no método da PSE da sessão. A carga de treinamento com base na PSE da sessão não é influenciada pela maturidade biológica e desempenho específico no atletismo, portanto, pode ser usada para controlar a carga de treinamento de jovens atletas de atletismo. Para as meninas é necessário cuidado para controlar a intensidade das sessóes de treino de $250 \mathrm{~m}$ de corrida.

Palavras-chave: Esforço físico; Monitoramento; Treinamento.
1 University of São Paulo. Department of Sport. School of Physical Education and Sport. Endurance Sports Research Group. São Paulo, SP. Brazil.

2 Federal University of Paraná. Departament of Physical Education. Curitiba, PR. Brazil.

3 Federal University of Juiz de Fora. School of Physical Education and Sport. Juiz de Fora, MG. Brazil.

4 Federal University of Ouro Preto. School of Physical Education. Laboratry of Studies and Reserch of Exercise and Sport. Ouro Preto, MG. Brazil.

5 Federal University of Lavras. Departament of Physical Education. Lavras, MG. Brazil.

Received: 13 December 2018 Accepted: 20 July 2019

How to cite this article Cruz R, Alves DL, Domingos PR, Freitas JV, Werneck FZ, Bertuzzi R, De-Oliveira FR, Lima JRP. Do biological maturity and performance influence the training load of track and field athletes? Rev Bras Cineantropom Desempenho Hum 2019, 21:e60662. Dol: http://dx.doi. org/10.1590/1980-0037.2019v21e60662

Copyright: This work is licensed under a Creative Commons Attribution 4.0 International License. 


\section{INTRODUCTION}

One of the main objectives of sports training is increases the performance. In order to reach this objective it is necessary a harmonic relationship between the training load (TL) and adequate recovery ${ }^{1,2}$. In this sense, quantify the TL is critical to the success of training. It was proposed a method to control the TL based on the RPE-training session ${ }^{3,4}$. In this way, there are several studies demonstrating the scientific validity and practical application of this method ${ }^{1,5-7}$. To track and field, we already demonstrated that girls have more RPE-training sessions than boys to running training-

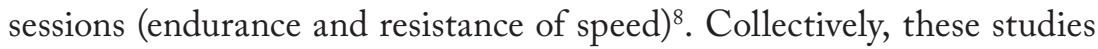
have suggested that RPE-training session is sensitive enough to indicate how the athletes perceive the training intensity.

Despite the TL be considered important to athletic performance optimization, the biological maturity (BM) also must be considered, in particular, in young athletes (13 - 15 years). For example, Figueiredo, Coelho e Silva and Malina ${ }^{9}$ demonstrated that the subjects with advanced BM stage have greater anthropometric development and better performance in aerobic and anaerobic tests. In addition, study showed that chronological and maturational age, training experience and body size lead to individual differences among young female basketball players ${ }^{10}$. Besides the physical changes, alters caused by BM could influence physical activity level, psychological status and behavior ${ }^{11-13}$. Therefore, it is possible to hypothesize that the psychometric variables could be influenced by BM. Nonetheless, to the best of our knowledge, there are no studies that have investigated the possible association between BM and TL, more specifically based on the method of RPE-training session.

Concerning about the performance of a physical test can influence the RPE-training session, there are previous investigations demonstrating that ${ }^{14-16}$. An investigation with professional basketball players, it was demonstrated that the subjects with better performance on Yo-Yo Test tend to report lower values of RPE-training session $(r=-0.68, p=0.06$, $\mathrm{n}=8)^{15}$. This result was corroborated by Marcelino et al. ${ }^{14}$ that indicated young basketball players with better performance in Yo-Yo Test reported lower RPE-training session values, showed a negative correlation between variables $(r=-0.80, p<0.05, \mathrm{n}=12)$. In this sense, Milanez et al. ${ }^{16}$ found a significant association $(r=-0.75, p<0.05, \mathrm{n}=9)$ between $\mathrm{VO}_{2} \max$ in incremental test on the treadmill and RPE-training session. Despite important advances to understand how the RPE-training session can be influenced by Yo-Yo test (aerobic fitness) it is necessary to further investigate about this topic, considering more tests based on different sports to ensure the ecological validity. Our previous study shown that for training of 250 and 1000-meters females related higher RPE-values than males, and this difference persisted even when biological maturity effect was controlled. Taken together, besides the understanding established previously about how girls and boys could perceived different the track and field trainingsession $^{8}$; it is necessary to clarify if BM and track and field performance 
can modulate the perception about training-session.

Faced with the need to understand how the RPE-training session could be influenced, the purpose of this study was to verify if the BM and specific performance (SP) could be associated with TL based on RPEtraining session.

\section{METHOD}

\section{Participants}

Seventy-five young athletes, of the same category (under-16) of both genders (38 boys and 37 girls) participated in the present study. All participants and their respective responders received a verbal explanation about this research and written informed consent before participation in the study. The study was approved by the local Ethics Committee for Human Studies (number 945.274) and was performed in accordance with the ethical standards laid down in the Declaration of Helsinki.

\section{Design}

The experimental sessions were performed for seven consecutive days. In the first session, it was performed anthropometric measures, filled out an anamnesis and track and field performance tests. The disciplines that were considered for performance tests represent running (75, 250 and 1000-m running), jump (long jump) and throw (shot put). After 48 hours of the first session, five consecutive days of track and field training was prescribed, each day represent a typical training of each SP test. All the athletes were instructed to avoid foods containing caffeine and refrain from any exhaustive or unaccustomed exercise during the preceding $24 \mathrm{~h}$ of the first day. During the days of training sessions they were instructed to keep their same pattern of feed. 30 minutes after each training sessions it was asked to athletes the RPE-training session.

\section{Procedures}

\section{- Anthropometry measurements and biological maturity}

Anthropometry measurements were performed according to the procedures described by $\mathrm{ISAK}^{17}$. Participants were weighed to the nearest $0.1 \mathrm{~kg}$ using an electronic scale (Filizola, model ID 1500, São Paulo, Brazil). Height was measured to the nearest $0.1 \mathrm{~cm}$ using a portable stadiometer (Welmy, model W200/5, Santa Bárbara d'Oeste, Brazil). Skinfold thickness was measured to the nearest $0.1 \mathrm{~mm}$ at four body sites (i.e. subscapularis, supra iliac, triceps and leg) using an adipometer (Sanny, Model Classic Scientific, São Bernardo do Campo - Brazil). The median of three values of skinfolds it was used.

The method of The Predicted Mature Stature (PMS) was used to estimate the BM. This non-invasive method was proposed by Khamis and Roche $^{18,19}$ and is based on decimal age, anthropometry measurements of athletes (weight and stature), and their parents. The equation has specific coefficients for each variable, according to the age of the subject. PMS 
express the stature that the athletes could reach in the adulthood. The percentage of PMS (PPMS) it is obtained by the following equation, PPMS $=100^{*}$ (Current Height/PMS). Besides that, this method has been largely used to estimate the biological maturity ${ }^{8,20,21}$.

\section{- Performance tests}

To increase the ecological validity of the present study the SP tests were determined in accordance with Brazilian Track and Field Federation that considers for this category of these official disciplines. The choose of performance tests have considered one discipline to represent speed (75 $\mathrm{m})$, resistance of speed (250 m), endurance running (1000 m), jump (long jump) and throw (shot put). To performance test it was considered the following order: 75-m, long jump, 250-m, shot put and 1000-m. There was 15 minutes to recovery between the tests and was given 5 minutes to warm-up again. Before the performance tests the athletes performed 10-min to warm-up and 5 minutes to light stretching. On the track tests, the athletes were encouraged to cover the distance as fast as possible, as well as, on the field tests the athletes were motivated to jump and throw the more distance possible.

The tests of speed (75-m running) and resistance of speed (250-m running) were performed individually, the test was started after the commands "On your marks, set, go". To the 1000 -m running the athletes were divided into groups by gender and of up to 12 runners, and then performed the test on a 400-m track and field. The participants were instructed to finish the race as quickly as possible. To the field tests were given 3 attempts for each athlete on the long jump and also shot put. It was considered at least 5 minutes between each attempt.

\section{- Training Sessions}

The aim of training sessions were reproduced the typical training of each discipline of track and field to the under-16 category. Previously experimental procedures, all coaches were consulted and ensured that their athletes were familiarized with structure and all activities proposed. All training sessions have the same structure and duration, they have 120 minutes, divided by warm-up (10 min) and stretching ( $5 \mathrm{~min}$ ), main part (90 min) and active recovery (jogging and lightly stretching $-15 \mathrm{~min}$ ). The table 1 summarized the characteristics of the main part of each training session.

\section{- Training Load}

To estimate the TL it was used the RPE-method, 30 minutes after the training session was asked to athletes "How was your workout?". The value of TL is obtained by multiplying the RPE value with training session duration (in minutes).

\section{Statistical Analysis}

Data normality was assessed by Kolmogorov Smirnov. The results of the descriptive statistics were reported as means and SD. Spearman's Who 
Table 1. Descriptive characteristics of training sessions.

\begin{tabular}{|c|c|c|c|c|c|}
\hline $\begin{array}{l}\text { Duration } \\
\text { (min) }\end{array}$ & $\begin{array}{l}75-m \\
\text { running }\end{array}$ & $\begin{array}{l}\text { Long } \\
\text { Jump }\end{array}$ & $\begin{array}{l}250-m \\
\text { running }\end{array}$ & $\begin{array}{l}\text { Shot } \\
\text { Put }\end{array}$ & $\begin{array}{l}100-m \\
\text { running }\end{array}$ \\
\hline 15 & \multicolumn{5}{|c|}{ Warm-up and stretching } \\
\hline 90 & $\begin{array}{l}\cdot 10 \times \text { Technical run } \\
\text { with low intensity } \\
(40-\mathrm{m}) \\
\cdot 5 \times \text { Individual short } \\
\text { sprints (15-m) } \\
\cdot 10 \times \text { Competition } \\
\text { short sprints }(10-m)\end{array}$ & $\begin{array}{l}-14 \times \text { Drills of take-off } \\
3 \text { steps } \\
-10 \times \text { Drills of take-off } \\
5 \text { steps } \\
\cdot 3 \times \text { Approach run- } \\
\text { ning to jump } 13 \text { steps } \\
\bullet 6 \times \text { Five bound } \\
\text { jumps }\end{array}$ & $\begin{array}{l}-10 \times \text { Technical run } \\
\text { with low intensity } \\
(60 \text {-m) } \\
\cdot 4 \times \text { Individual short } \\
\text { sprints }(50-m) \\
\text { - Competition sprints: } \\
1 \times 50-m ; 1 \times 100-m ; \\
1 \times 150-m .\end{array}$ & $\begin{array}{l}-30 \times \text { Technical of } \\
\text { shot put throw (mass } \\
\text { of shot } 0.5 \mathrm{~kg} \text { ) } \\
\cdot 3 \times \text { Usage technic } \\
\text { (official shot put) } \\
\text { - } 60 \times \text { Throw resist- } \\
\text { ance training (medi- } \\
\text { cine ball } 1.0 \mathrm{~kg} \text { ) }\end{array}$ & $\begin{array}{l}-4 \times \text { Interval training } \\
45-\mathrm{m} \text { running at and } \\
20-\mathrm{m} \text { active recovery } \\
-4 \times 2 \text { minutes run- } \\
\text { ning at } 85 \% \text { of } \mathrm{V} 1000- \\
\mathrm{m} \text { running } \\
-10 \text { minutes of Fartlek }\end{array}$ \\
\hline 15 & Active recovery & & & & \\
\hline
\end{tabular}

correlation was used to analyze the relationship between TL with BM and SP. Statistical significance was set at $p<0.05$.

\section{RESULTS}

The mean of age was $14.30 \pm 0.8514 .55 \pm 0.82$, to boys and girls, respectvelly. Additionaly, the BM based PPMS (\%) to boys was $94.26 \pm 4.18$ and to girls $98.00 \pm 1.49$. Further descriptive characteristics has been described in detail previously ${ }^{8}$. The table 2 presents the SP tests of participants.

Table 2. Specific performance tests (mean \pm SD).

\begin{tabular}{lcc}
\hline Specific Performance & Boys & Girls \\
\hline 75 -m & $10.64 \pm 1.26$ & $11.46 \pm 0.77$ \\
Long Jump & $4.76 \pm 0.82$ & $3.87 \pm 0.50$ \\
250 -m & $40.32 \pm 6.58$ & $44.10 \pm 4.90$ \\
Shot Put & $7.90 \pm 1.66$ & $6.52 \pm 1.20$ \\
1000 -m & $242.95 \pm 51.72$ & $277.38 \pm 37.32$ \\
\hline
\end{tabular}

The table 3 shown the TL of all training. The training session of long jump had the lowest value of TL, while the training session of 1000 meters had the highest value of TL.

Table 3. Values of training load of each training session (mean \pm SD).

\begin{tabular}{lcc}
\hline \multirow{2}{*}{ Training Session } & \multicolumn{2}{c}{ Training Load (a. u.) } \\
\cline { 2 - 3 } & $388.42 \pm 92.25$ & Girls \\
\hline $75-\mathrm{m}(\mathrm{s})$ & $364.74 \pm 80.60$ & $384.32 \pm 0.77$ \\
Long Jump (m) & $391.58 \pm 67.96$ & $369.73 \pm 0.50$ \\
$250-\mathrm{m}(\mathrm{s})$ & $364.74 \pm 82.98$ & $442.70 \pm 4.90$ \\
Shot Put (m) & $446.84 \pm 106.87$ & $377.84 \pm 1.20$ \\
$1000-\mathrm{m}(\mathrm{s})$ & & $497.84 \pm 113.02$ \\
\hline
\end{tabular}

The table 4 shown the result of Spearman's Who correlation. Even though the significant result between the TL of 250-m training session with BM and SP (weak association and only to girls), a general way, there 
is no the relationship between this variables. In this sense, the method to control the TL based on RPE-training session is safety even young athletes within the BM process and SP.

Table 4. Spearman's Who correlation.

\begin{tabular}{lcccc}
\hline \multirow{2}{*}{ Training load } & \multicolumn{2}{c}{ Specific Performance } & \multicolumn{2}{c}{ Biological Maturity } \\
\cline { 2 - 5 } & Boys & Girls & Boys & Girls \\
\hline 75-m & 0.03 & 0.15 & -0.19 & -0.14 \\
Long Jump & -0.28 & 0.11 & -0.01 & -0.14 \\
250-m & 0.16 & $0.33^{\star}$ & -0.09 & $-0.36^{\star}$ \\
Shot Put & 0.12 & -0.31 & -0.10 & -0.29 \\
1000-m & -0.12 & 0.26 & -0.02 & -0.15 \\
\hline
\end{tabular}

Note. $p<0.05$.

\section{DISCUSSION}

The aim of the present study was to verify if the BM and SP could be associated with TL based on RPE-training session. It was found that there were not relationship between these variables. To the best of our knowledge, this is the first study to consider the BM and SP could to influence the athletes RPE-training session. This result suggests and supports that coaches and researchers of sports can use the RPE-training session method to quantify the TL with young athletes during the BM process and different performance in track and field training.

Recent studies have demonstrated the endurance level can influence de RPE-training session ${ }^{14-16}$, indicating the athletes with higher $\mathrm{VO}_{2} \max$ perceived lower values of RPE-training session, and therefore, lower TL values. These studies suggested that a great recovery is caused by advanced aerobic metabolism; hence, the mechanism related to Phosphocreatine resynthesis allows athletes to have a faster recovery and lower feel of fatigue $^{15,16}$. The test to determine the endurance fitness of athletes was Yo-Yo test, and it was chosen because is similar to the game dynamic (basketball and futsal). Furthermore, another study highlighted the importance of physical fitness to determine the $\mathrm{TL}^{22,23}$. For this reason, for track and field is important to consider specifics tests of performance, additionally, these tests must represent (or must be similar) the disciplines of this modality.

The results of the present study indicated that SP of track and field does not influence the TL of any kind training session (speed, resistance of speed, jump, throws and endurance). In accordance with methodological procedures propose by Foster et al. ${ }^{4}$, the athletes must indicate how was felt about the training. In this sense, the SP could not influence this indicate because during the track and field training sessions exercises is stipulated based on individual parameters, thereby, the physical efforts are relativized by athletes themselves. The values of association to girls $(r=0.33, p=$ $0.04, \mathrm{n}=37$ ) during the $250-\mathrm{m}$ training session were significant, despite that, slightly more than $10 \%$ can explain by the relationship between both 
variables. Therefore, during the training sessions with an anaerobic capacity characteristic, the girls have lower performance on disciplines predominantly lactic-anaerobic, such as $250-\mathrm{m}$ running ${ }^{24-27}$ need a special attention concerning the TL. How it was described in this investigation, regardless of young athletes, it is important to consider the BM. A previous studies showed that older runners (under 16) showed higher acceleration $(15 \mathrm{~m})$ and modified agility test to younger runners (under 14) ${ }^{28}$, suggests that $\mathrm{BM}$ should be considered when the physical and technical parameters are evaluated. In this sense, studies have been demonstrating his implication of physical development and performance ${ }^{9,11}$.

A study with 143 young football players, Figueiredo et al. ${ }^{9}$ demonstrated that the performance in predictors of functional capacities (younger $37 \%$, older 58\%) and soccer skills tests (younger 26\%, older 18\%) had a great association with BM. In another study, Jones et al..$^{29}$ have indicated the performance in the vertical jump, hand grip strength and the $20-\mathrm{m}$ shuttle run test it was also associate with BM. A recent study found that BM influenced the anthropometric and physical performance determinants of Australian Football ${ }^{13}$. Malina et al. ${ }^{11}$ highlighted that psychological factor is changed during BM. In this sense, it is rational to consider with according to the BM stage, the perceptions variable could be altered. However, our result indicated that there was not a significant association between TL based on RPE-training session and BM. This result corroborates with the case of SP. Once again, the RPE-training session method resists the different stage of BM, this fact, can be explained because track and field's training session often is relativized per athlete. Moreover, our methodological procedure was well controlled and prescribed for each athlete, what has strengthened these result.

Concerning the girls, it must be considered there was a significant association BM and TL of 250-m, in which the most advanced BM have indicated lower values of TL $(r=-0.36, p=0.02, \mathrm{n}=37)$. As was happen with SP and TL, we preconized that during training sessions with this characteristics, coaches must be more careful concern girls training. For the training sessions with other characteristics, such as, speed, jumps and throws, our results indicated that the RPE-training session, in a general way, does not suffer the influence of BM stage.

\section{CONCLUSIONS}

In summary, the results of the present study have indicated that TL based on RPE-training session is not influenced by BM and track and field SP, therefore can be used to control the TL of young track and field athletes. To girls it is necessary a care to control the training sessions intensity of 250-m running.

\section{Acknowledgements}

The authors thank CAPES for scholarship and all teams and athletes of track and field for their participation. 


\section{COMPLIANCE WITH ETHICAL STANDARDS}

\section{Funding}

This research did not receive any specific grant from funding agencies in the public, commercial, or not-for-profit sectors. This study was funded by the authors.

\section{Ethical approval}

Ethical approval was obtained from the local Human Research Ethics Committee -Federal University of Juiz de Fora and the protocol (no. 34366814.7.0000.5147) was written in accordance with the standards set by the Declaration of Helsinki.

\section{Conflict of interest statement}

The authors have no conflict of interests to declare.

\section{Author Contributions}

Conceived and designed the experiments: RC, FRO, JRPL. Performed the experiments: RC, DLA, JVF. Analyzed the data: RC, RB, FZW. Contributed reagents/materials/analysis tools: RC, FRO, JRPL. Wrote the paper: RC, PRD, DLA.

\section{REFERENCES}

1. Borresen J, Lambert MI. The quantification of training load, the training response and the effect on performance. Sport Med 2009;39(9):779-95.

2. Meeusen R, Duclos M, Foster C, Fry A, Gleeson M, Nieman D, et al. Prevention, diagnosis and treatment of the overtraining syndrome: Joint consensus statement of the European College of Sport Science (ECSS) and the American College of Sports Medicine (ACSM). Eur J Sport Sci 13:1-24.

3. Foster C, Daines E, Hector L, Snyder AC, Welsh R. Athletic performance in relation to training load. Wis Med J 1996;95(6):370-4.

4. Foster C, Florhaug JA, Franklin J, Gottschall L, Hrovatin LA, Parker S, et al. A new approach to monitoring exercise training. J Strength Cond Res 2001 Feb;15(1).

5. Suzuki S, Sato T, Maeda A, Takahashi Y. Program design based on a mathematical model using rating of perceived exertion for an elite japanese sprinter: acase study. J Strength Cond Res 2006;20(1):36-42.

6. Cruz R, Bertuzzi RC, Alves DL, Azevedo R, Castro PH, Freitas JV, et al. Factors determining 800-m running performance in young male athletes. J Sports Med Phys Fitness 2018;58(6).

7. Lambert M, Borresen J. A theoretical basis of monitoring fatigue: a practical approach for coaches. Int J Sports Sci Coach 2006;1(4):371-88.

8. Cruz R, Alves DL, Azevedo R, Bertuzzi R, De-Oliveira FR, Lima JRP. Monitoring the training intensity and recovery with a psychometrics approach: a gender comparison with young athletes. Motriz: J Phys Ed 2017;23(3):1-5.

9. Figueiredo AJ, Coelho e Silva MJ, Malina RM. Predictors of functional capacity and skill in youth soccer players. Scand J Med Sci Sports 2011;21(3):446-54.

10. Leonardi TJ, Paes RR, Breder L, Foster C, Gonçalves CE, Carvalho HM. Biological maturation, training experience, body size and functional capacity of adolescent female basketball players: A Bayesian analysis. Int J Sports Sci Coach 2018;1747954118772489.

11. Malina RM, Bouchard C, Bar-Or O. Growth, maturation, and physical activity. Human Kinetics; 2004. 
12. Sherar LB, Cumming SP, Eisenmann JC, Baxter-Jones ADG, Malina RM. Adolescent biological maturity and physical activity: biology meets behavior. Pediatr Exerc Sci 2010;22(3):332-49.

13. Cripps AJ, Joyce C, Woods CT, Hopper LS. Biological maturity and the anthropometric, physical and technical assessment of talent identified U16 Australian footballers. Int J Sports Sci Coach 2017;12(3):344-50.

14. Marcelino PR, de Arruda AFS, Oliveira R de, Saldanha Aoki M, Freitas CG, Moreira A. ¿ El nivel de condición física puede influir en la magnitud de la carga interna del entrenamiento en jóvenes jugadores de baloncesto? Rev Andaluza Med del Deport 2013;6(3):115-9.

15. Manzi V, D’Ottavio S, Impellizzeri FM, Chaouachi A, Chamari K, Castagna C. Profile of Weekly Training Load in Elite Male Professional Basketball Players. J Strength Cond Res 2010;24(5):1399-406.

16. Milanez VF, Pedro RE, Moreira A, Boullosa DA, Salle-Neto F, Nakamura FY. The role of aerobic fitness on session rating of perceived exertion in futsal players. Int J Sport Physiol Perform 2011;6(3):358-66.

17. MacDougall JD, Wenger HA, Green HJ. Physiological testing of the highperformance athlete. Champaign, Ill.: Human Kinetics Books; 1991.

18. Khamis HJ, Roche AF. Predicting adult stature without using skeletal age: the Khamis-Roche method. Vol. 94, Pediatrics. Am Acad Pediatrics; 1994. p. 504-7.

19. Khamis HJ, Roche AF. Growth Outcome of "Normal" Short Children who are Retarded in Skeletal Maturation. J Pediatr Endocrinol Metab 1995;8(2):85-96.

20. Bidaurrazaga-Letona I, Carvalho HM, Lekue JA, Santos-Concejero J, Figueiredo AJ, Gil SM. Longitudinal field test assessment in a Basque soccer youth academy: A multilevel modeling framework to partition effects of maturation. Int J Sports Med 2015;36(3):234-40.

21. Valente-Dos-Santos J, Coelho-E-Silva MJ, Machado-Rodrigues AM, ElferinkGemser MT, Malina RM, Petroski ÉL, et al. Prediction equation for lower limbs lean soft tissue in circumpubertal boys using anthropometry and biological maturation. Plos One 2014;9(9):e107219.

22. Los Arcos A, Martínez-Santos R, Yanci J, Mendiguchia J, Méndez-Villanueva A. Negative associations between perceived training load, volume and changes in physical fitness in professional soccer players. J Sports Sci Med 2015;14(2):394.

23. Halson SL. Monitoring Training Load to Understand Fatigue in Athletes. Vol. 44, Sports Medicine. Springer; 2014. p. 139-47.

24. Hegge AM, Myhre K, Welde B, Holmberg HC, Sandbakk Ø. Are gender differences in upper-body power generated by elite cross-country skiers augmented by increasing the intensity of exercise? Plos One 2015;10(5):e0127509.

25. Sandbakk $\varnothing$, Ettema G, Holmberg H. Gender differences in endurance performance by elite cross-country skiers are influenced by the contribution from poling. Scand J Med Sci Sports 2014;24(1):28-33.

26. Seiler S, De Koning JJ, Foster C. The fall and rise of the gender difference in elite anaerobic performance 1952-2006. Med Sci Sports Exerc 2007;39(3):534.

27. Weber CL, Chia M, Inbar O. Gender differences in anaerobic power of the arms and legs-a scaling issue. Med Sci Sports Exerc 2006;38(1):129.

28. Yanci J, Cámara J, Vizcay JJ, Young WB. Examining age and gender effects in physical performance in young athletes aged 12-16 years. Int J Sports Sci Coach 2016;11(4):538-44.

29. Jones MA, Hitchen PJ, Stratton G. The importance of considering biological maturity when assessing physical fitness measures in girls and boys aged 10 to 16 years. Ann Hum Biol 2000;27(1):57-65.

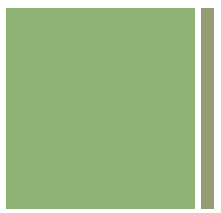

